\title{
Niemann - Pick disease associated with hemophagocytic syndrome
}

\section{Hemofagositik sendrom ve Niemann-Pick hastalığı birlikteliği}

\author{
Serap Karaman1, Nafiye Urganci2, Günsel Kutluk³, Feyzullah Çetinkaya3 \\ 1Department of Pediatric Hematology, Sisli Etfal Training and Research Hospital, Istanbul, Turkey \\ 2Department of Pediatric Gastroenterology, Sisli Etfal Training and Research Hospital, Istanbul, Turkey \\ ${ }^{3}$ Clinics of Pediatrics, Sisli Etfal Training and Research Hospital, Istanbul, Turkey
}

\begin{abstract}
A bstract
H emophagocytic lymphohistiocytosis (H LH) is a disease characterized by phagocytosis of blood cells by macrophages within the lymphoreticular tissue. It can develop secondary to some diseases or be familial as a result of genetic mutations. Niemann-Pick disease (NPD) is a very rare lipid storage disease. A three-month-old girl presented with high fever $\left(39^{\circ} \mathrm{C}\right)$, abdominal distension and paleness. The parents were consanguineous. The liver and spleen were palpable $10 \mathrm{~cm}$ and $11 \mathrm{~cm}$ below the costal margins, respectively. Bicytopenia ( $\mathrm{H}$ b: $5.5 \mathrm{~g} / \mathrm{dl}$, platelet: $\left.77000 / \mathrm{mm}^{3}\right)$, hypertriglyceridemia $(351 \mathrm{mg} /$ dl), hyperferritinemia (>1500 ng/dl) and hypofibrinogenemia $(120 \mathrm{mg} / \mathrm{dl}$ ) were detected. Bone marrow aspiration demonstrated foam cells and hemophagocytosis by macrophages and Niemann-Pick cells. Lysosomal sphingomyelinase activity was $0.24 \mathrm{nmol} / \mathrm{h} / \mathrm{mg} / \mathrm{protein}$ (normal: $0.86-2.8$ ). Due to the parents' refusal of further evaluation, the nature of $\mathrm{HLH}$ as primary or secondary could not be determined. To the best of our knowledge, this is the first case of NPD associated with HLH and the first demonstration of hemophagocytosis by Niemann-Pick cells. (Turk J Hematol 2010; 27: 303-7)

Key words: Niemann-Pick disease, hemophagocytic syndrome, hemophagocytosis by NiemannPick cell, hemophagocytosis, hemophagocytic lymphohistiocytosis, HLH
\end{abstract}

Received: May 19, 2010

Accepted: J uly 26, 2010

Ö zet

H emofagositik lenfohistiositoz (H LH), lenforetiküler dokudaki makrofajların kan hücrelerini fagosite etmesiyle karakterize olan, genetik olarak mutasyonlara bağlı ailevi veya bazı hastalıklara ikincil gelişen bir hastalıktır. N ieman-Pick hastalığı ise bir lipid depo hastalığı olup son derece nadir görülmektedir. Ü ç aylık kız hasta yüksek ates $\left(39^{\circ} \mathrm{C}\right)$, karın şişliği ve solukluk nedeni ile başvurdu. E beveynler arasında ikinci derecede akrabalık vard. $K$ araciğer $10 \mathrm{~cm}$, dalak $11 \mathrm{~cm}$ ele geliyordu.

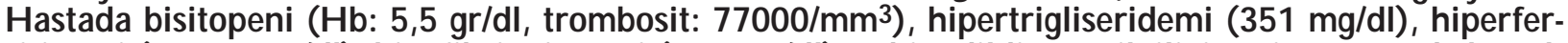
ritinemi (> 1500 ng/dl), hipofibrinojenemi (120 mg/dl) tesbit edildi. Kemik iliği aspirasyonunda köpük hücresi, makrofajlar ve Niemann-Pick hücreleri tarafından yapılan hemofagositoz görüldü. Lizozomal 


\begin{abstract}
sfingomyelinaz aktivitesi $0.24 \mathrm{nmol} / \mathrm{hr} / \mathrm{mg} / \mathrm{ptn}$ (normal:0.86-2.8) bulundu. H astadaki H L H 'nin primer veya sekonder olduğu, ailenin tetkiki kabul etmemesi nedeni ile incelenemedi. Olgumuz literatürde Niemann-Pick ile birlikte H LH 'nin saptandığı ilk vakadır ve Niemann-Pick hücresinin de hemofagositoz yaptığı ilk kez gösterilmiştir. (Turk J Hematol 2010; 27: 303-7)

A nahtar kelimeler: Niemann-Pick Hastalığı, hemofagositik sendrom, Niemann-Pick hücresinin hemofagositozu, hemafagositoz, hemofagositik lenfohistiositoz, HLH
\end{abstract}

\section{Introduction}

Niemann-Pick disease (NPD) is an autosomal recessive metabolic disorder characterized by sphingomyelin accumulation in certain tissues. Six subtypes of NPD have been described: type A-acute neuronopathic form, type B-visceral form, type C-chronic neuronopathic form, type D-Nova Scotia variant, which is mostly prevalent in the Nova Scotia region of west Canada, type $\mathrm{E}$ - adult form, and type F-Sea Blue histiocyte disease. All subtypes are inherited as autosomal recessive traits and display variable clinical features. Foam-cell infiltration and visceromegaly are common features in all forms, but neurologic involvement occurs only in types $A$ and $C$ and not in type $B$. Type $A$ is the most common type and occurs in infants. It is characterized by jaundice, an enlarged liver, and profound brain damage. Children with this type rarely live beyond 18 months. The clinical presentation and course in patients with type $B$ disease are variable. The condition is diagnosed in most patients in infancy or childhood when enlargement of the liver, spleen, or both is detected during routine physical examination. At diagnosis, patients with NPD type B also have evidence of mild pulmonary involvement, usually detected as a diffuse reticular or finely nodular infiltration on chest radiography. Foam-cell infiltration and visceromegaly are common features in all forms, but in types $A$ and $B$, sphingomyelinase enzyme activity is deficient, whereas in types $C$ and D, enzyme levels are almost normal [1-4].

Hemophagocytic lymphohistiocytosis (HLH) is characterized by sustained fever, spleen enlargement, cytopenias, hypertriglyceridemia and/or hypofibrinogenemia, hyperferritinemia, decrease or absence of natural killer (NK) cell activity, elevated levels of soluble CD 25, and hemophagocytosis in bone marrow, spleen and lymph node $[5,6]$. This syndrome may be primary, as a familial form, or it may develop secondary to viral, bacterial, fungal and parasitic infections, and collagen vascular, rheumatic and malignant diseases [7,8] .
We report the case of a three-month-old girl suffering from pallor and abdominal distension. She had lipid-laden foamy cells and hemophagocytosis in the bone marrow simultaneously. To our knowledge, this is the first concomitant occurrence of two separate diseases: HLH associated with Niemann-Pick.

\section{Case Report}

A three-month-old girl with a complaint of progressive abdominal distension and agitation was admitted to our hospital. According to the family history, she was delivered by cesarean section in the $38^{\text {th }}$ gestational week following a normal pregnancy, weighing $3200 \mathrm{~g}$. During the neonatal period, she had no problems such as jaundice or feeding difficulties but her family noted pallor and abdominal distension after the first month. Her parents were second-degree relatives and she was their first child. She had no lost siblings but two uncles of the patient died from an unknown disease in the first three months of life.

On the initial physical examination, her weight and height were in the $50^{\text {th }}$ percentile. She was pale, agitated, tachypneic (respiration rate: $50 / \mathrm{min}$ ) and tachycardic (heart rate: 140/min, rhythmic and no murmur). She also had mild jaundice and marked hepatosplenomegaly, which caused abdominal distension; the liver was firmly enlarged $10 \mathrm{~cm}$ below the right costal margin, and the spleen was palpated $11 \mathrm{~cm}$ below the left margin.

Initial biochemical investigations revealed the following: hemoglobin $6.3 \mathrm{~g} / \mathrm{dl}$, hematocrit $18.8 \%$,

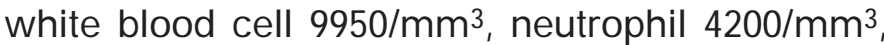
platelet count $103000 / \mathrm{mm}^{3}$, mean corpuscular volume (MCV) $72 \mathrm{fl}$, red cell distribution width (RDW) $16 \%$, mean corpuscular hemoglobin concentration $(\mathrm{MCHC}) 32 \mathrm{~g} / \mathrm{dl}$, alanine transaminase $142 \mathrm{U} / \mathrm{L}$, aspartate transaminase $346 \mathrm{U} / \mathrm{L}$, total bilirubin $3 \mathrm{mg} /$ $\mathrm{dl}$, conjugated bilirubin $2.29 \mathrm{mg} / \mathrm{dl}$, and serum lactate dehydrogenase (LDH) $2005 \mathrm{U} / \mathrm{L}$ levels were elevated. Renal function tests and electrolyte levels were in normal limits, but serum albumin level was 
$2.2 \mathrm{~g} / \mathrm{dl}$. Clotting tests were mildly deranged. Prothrombin activity was 56\%, international normalized ratio (INR) was 4.2 and activated partial thromboplastin time (aPTT) was $38.2 \mathrm{sec}$. Alpha-1 antitrypsin, hepatitis B markers, anti-HAV (hepatitis A virus), immunoglobulin $\mathrm{M}$, and $\mathrm{TORCH}$ (toxoplasmosis, rubella, cytomegalovirus, and herpesvirus) immunoglobulin $M$ values were interpreted as negative. Blood, urine and throat culture were also negative. Peripheral blood smear demonstrated normal red and white blood cell morphology; there were no atypical lymphocytes, and platelets were clustered. The chest radiograph revealed bilateral reticulonodular infiltration of the lungs. Abdominal ultrasonography revealed enlarged liver and spleen with increased echogenicity in the parenchyma. Diffuse ascites was also noted. A bone marrow aspi-

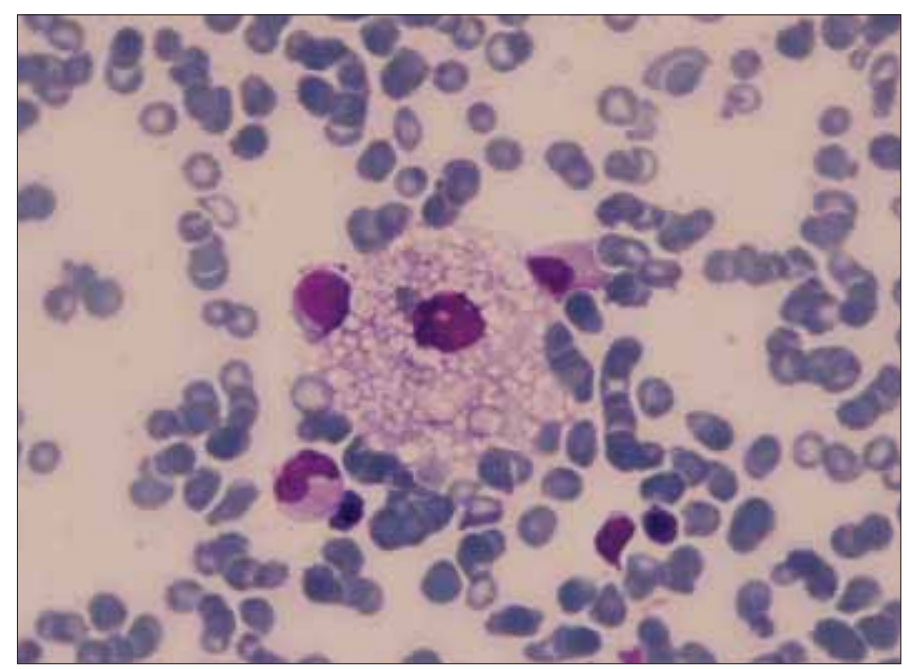

Figure 1. Lipid storaged macrophage and erytrocyte hemophagocytosis

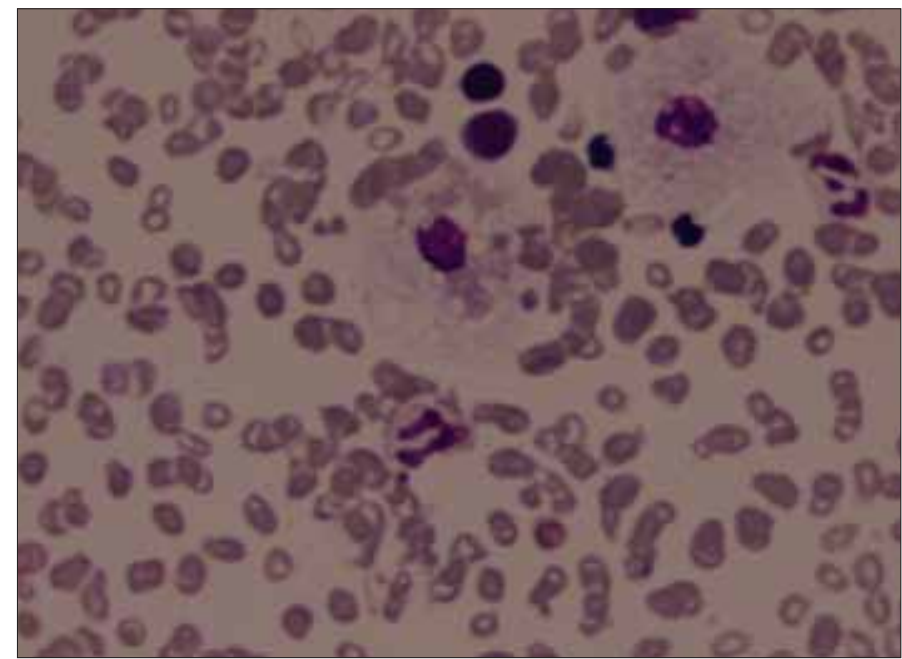

Figure 2. Lipid storaged macrophage and erytrocyte hemophagocytosis ration showed foamy macrophages with significantly vacuolated cytoplasm, called Niemann-Pick cells. These findings led us to NPD, and the diagnosis was confirmed by the measurement of the lysosomal sphingomyelinase activity: $0.24 \mathrm{nmol} / \mathrm{h} / \mathrm{mg} /$ protein (normal: 0.86-2.8). During the follow-up, the patient had lethargy and high fever four days later. On physical examination, her general appearance was not well, and her rectal temperature was $39^{\circ} \mathrm{C}$. Laboratory studies revealed the following: hemoglobin $5.5 \mathrm{~g} / \mathrm{dl}$, white blood cell $3300 / \mathrm{mm}^{3}$, platelets $77000 / \mathrm{mm}^{3}$, serum ferritin $(>1500 \mathrm{ng} / \mathrm{ml}$ ) and triglycerides (351 mg/dl) were significantly elevated and fibrinogen concentration was $120 \mathrm{mg} / \mathrm{dl}$. Repeated bone marrow aspiration showed Niemann-Pick cells (Figures 1-4) and macrophages (Figures 5,6) with marked erythrophagocytic and

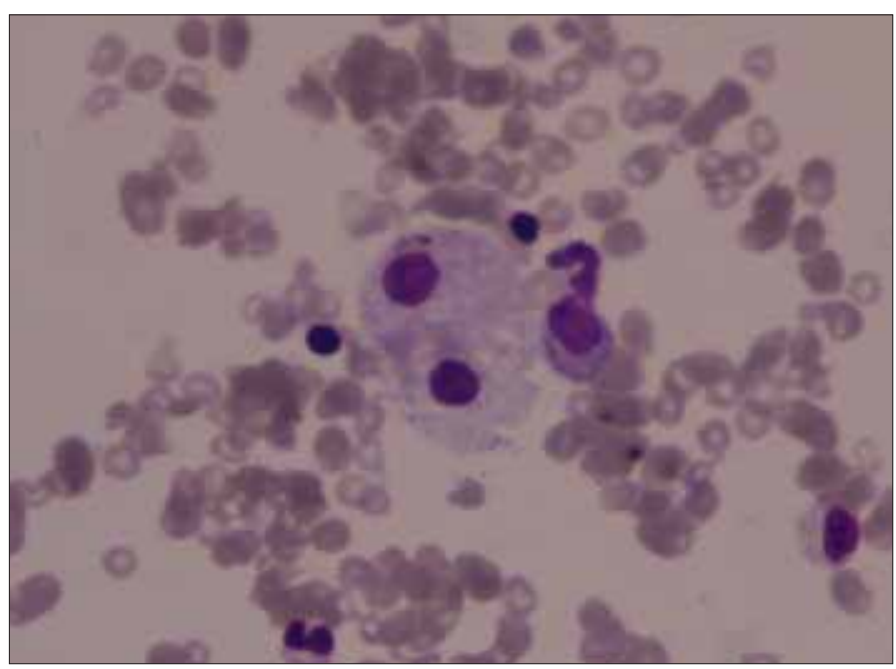

Figure 3. Lipid storaged macrophage, erythrocyte and thrombocyte hemophagocytosis

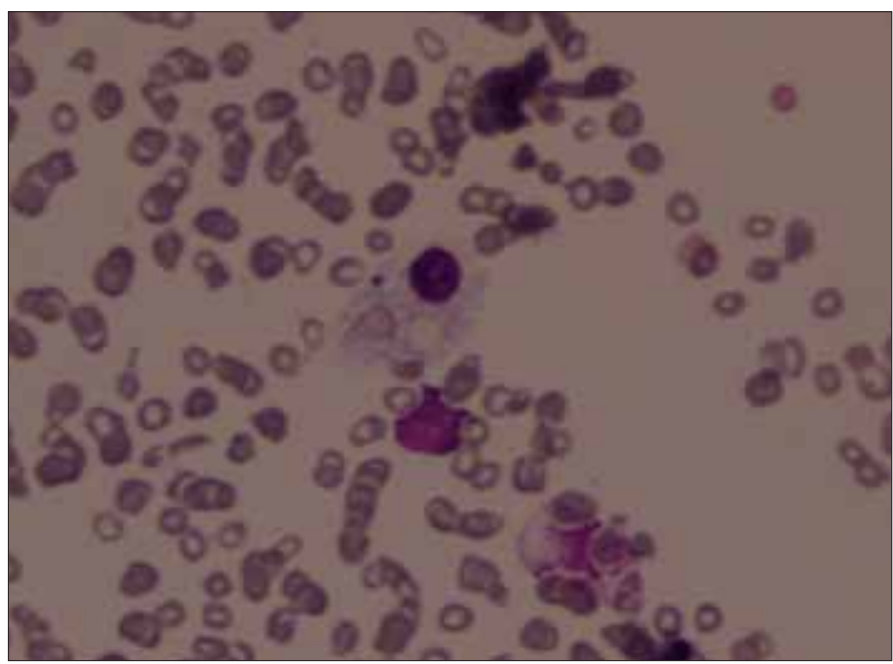

Figure 4. Lipid storaged macrophage, erythrocyte and thrombocyte hemophagocytosis 


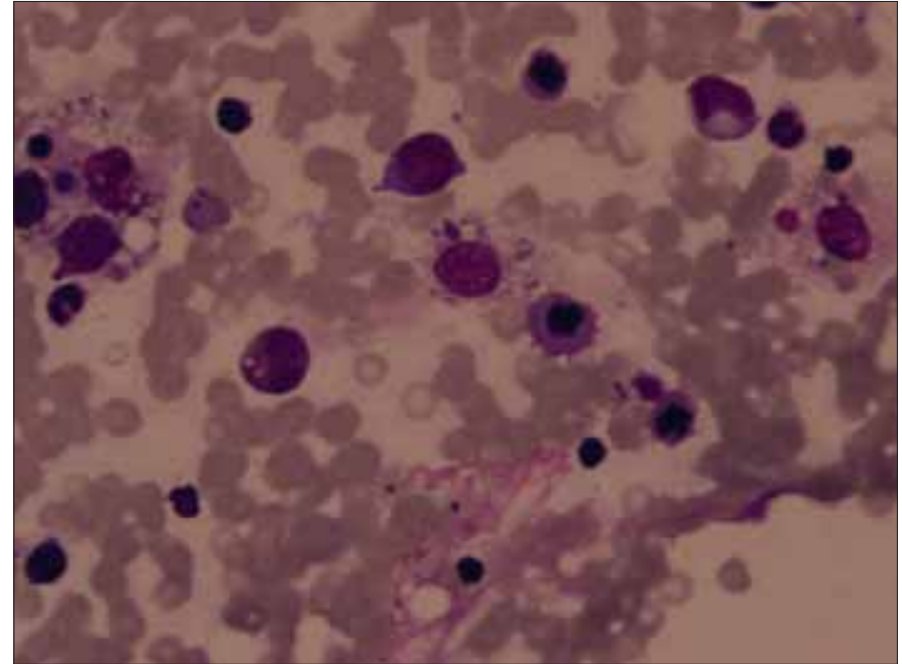

Figure 5. Erythrocyte and thrombocyte hemophagocytosis

thrombophagocytic activity. Hemophagocytic syndrome associated with NPD was considered based on these findings. The criteria of the Histiocyte Society were used for the diagnosis of HLH [7]. We could not study the NK cell activity or levels of CD25, but our case fulfilled the other criteria.

Treatment was initiated with intravenous immunoglobulin (IVIG) $0.8 \mathrm{mg} / \mathrm{kg}$, and transfusions of fresh frozen plasma and erythrocyte suspension were administered. We also decided to proceed with HLH-2004 protocol as immunosuppressive therapy. However, the parents declined further evaluation and treatment, so the patient was discharged without any treatment while clinical findings of the disease continued. It was learned that the patient died 10 days after the diagnosis.

Written informed consent was obtained from the patient's family.

\section{Discussion}

Niemann-Pick disease (NPD) refers to a group of inherited metabolic disorders known as the leukodystrophies or lipid storage diseases, in which harmful quantities of a fatty substance (lipids) accumulate in the spleen, liver, lungs, bone marrow, and the brain. This lipid storage disorder results from the deficiency of a lysosomal enzyme, acid sphingomyelinase. NPD is a very rare autosomal recessive disease. Our patient had marked hepatosplenomegaly, reticulonodular infiltration in the lungs, foam-cell infiltration in the bone marrow, and sphingomyelinase enzyme deficiency, but she had

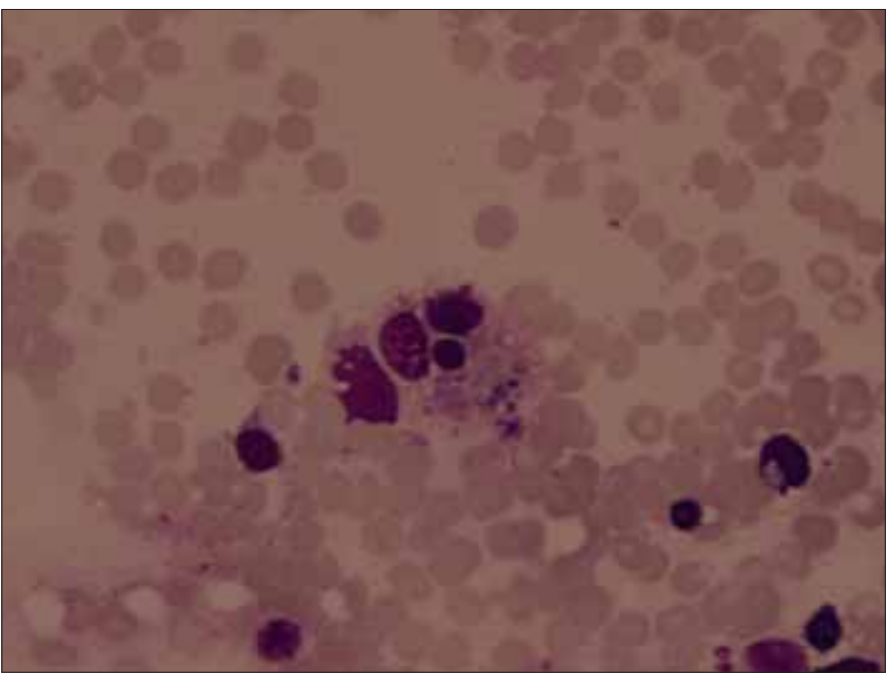

Figure 6. Erythrocyte and thrombocyte hemophagocytosis

no neurologic findings, so we assumed that she was more likely to be NPD type B [1,2].

On the other hand, hemophagocytic syndrome is a mostly fatal condition of severe hyperinflammation caused by the uncontrolled proliferation of activated lymphocytes and histiocytes secreting high amounts of inflammatory cytokines. As mentioned previously, HLH may develop secondary to viral, bacterial, fungal and parasitic infections, or collagen vascular, rheumatic and malignant diseases. It can also occur in the course of metabolic diseases. Although an association between amino acid metabolism disorders such as lysinuric protein intolerance and HLH was reported, there is no documented case in the literature about HLH secondary to a lipid storage disease $[9,10]$.

Both primary and secondary HLH are more common in our country than elsewhere [11-14]. As the disease shows autosomal recessive inheritance, it is probable that the present case, with parental consanguinity, might have had a primary HLH. Unfortunately, the patient died within a short period of time. Due to the parents' refusal of further evaluation, it could not be determined whether the HLH was primary or secondary in this patient. The patient was lost within 10 days most probably because of HLH since she did not receive chemotherapy. Although early deaths can also be seen in some types of NPD, the death of the patient immediately following the onset of high fever led us to believe that the cause may have been due to HLH. Persistence of severe disease despite IVIG therapy is consistent with primary HLH since most of the secondary HLH cases except in some disorders such as 
infectious mononucleosis show a good response to IVIG therapy [14]. On the other hand, in the present case, the consanguinity of the parents, early death within 10 days with $\mathrm{HLH}$ and other infant deaths in the family may suggest the presence of familial $\mathrm{HLH}$. If this case had a familial HLH, there should be a severe mutation. In previous studies from our country, it was reported that the perforin gene W374X mutation was responsible for familial HLH cases presenting within six months of life. This is also the most common mutation in our country and leads to death within a very short time after the presentation of the disease [11]. Since the genetic analysis could not be done, we can not comment on whether this case is a Niemann-Pick associated with familial HLH or a secondary case. In the present study, it is interesting that Niemann-Pick cells also exhibited hemophagocytosis. As far as we know, phagocytosis by Niemann-Pick cells has not been described until now.

In conclusion, NPD and HLH are within the group of rare diseases. It is not surprising to diagnose this association, since both are autosomal recessive disorders in our country where consanguineous marriages are frequent. Clinicians must be aware of HLH developing in NPD. Clinical and laboratory findings of Niemann-Pick such as hepatosplenomegaly and cytopenia may mask the diagnosis of HLH.

\section{Conflict of Interest}

No author of this paper has a conflict of interest, including specific financial interests, relationships, and/or affiliations relevant to the subject matter or materials included in this manuscript.

\section{References}

1. Vanier MT. Disorders of sphingolipid metabolism. In: Fernandes J, Soudubary J M, Berghe VG, Walter HJ , editors. Inborn Metabolic Disease, 4th ed. Berlin: Springer Heidelberg, 2006:482-92.

2. Margaret $M$, Destinck DJ. Lipidosis. In: Kliegman R, Behrman $\mathrm{R}$, Jenson $\mathrm{H}$, editors. Nelson Textbook of Pediatrics, 18th ed. Philadelphia: WB Saunders Company, 2007:593-600.
3. Watts RWE. Lysosomal storage disease. In: Weatherall DJ , Warrell DA, editors. Oxford Textbook of Medicine, 3rd ed. Oxford: Oxford University Press, 1996:1426-37.

4. McGovern MM, Desnick RJ. Lysosomal storage disease. In: Goldman L, Ausiello D, editors. Cecil Textbook of Medicine, 23rd ed. Philadelphia, PA: W.B. Saunders Company, 2008:1572-3.

5. Lipton J. Histiocytosis syndromes. In: Lanzkowsky P, editor. Manual of Pediatric Hematology and Oncology, 4th ed. San Diego: Academic Press, 2005:604-29.

6. Henter JI, Horne A, Aricó M, Egeler RM, Filipovich AH, Imashuku S, Ladisch S, McClain K, Webb D, Winiarski J, Janka G. HLH-2004: diagnostic and therapeutic guidelines for hemophagocytic lymphohistiocytosis. Pediatr Blood Cancer 2007;48:124-31.

7. Janka GE. Hemophagocytic syndromes. Blood Rev 2007;21:245-53.

8. Gurgey A, Secmeer G, Tavil B, Ceyhan M, Kuskonmaz B, Cengiz B, Ozen H, Kara A, Cetin M, Gumruk F. Secondary hemophagocytic lymphohistiocytosis in Turkish children. Pediatr Infect Disease J 2005;24:1116-7.

9. Doireau V, Fenneteau O, Duval M, Perelman S, Vilmer E, Touati G, Schlegel N, Ogier de Baulny H. Lysinuric dibasic protein intolerance: characteristic aspects of bone marrow involvement. Arch Pediatr 1996;3:877-80.

10. Duval M, Fenneteau O, Doireau V, Faye A, Emilie D, Yotnda P, Drapier JC, Schlegel N, Sterkers G, de Baulny $\mathrm{HO}$, Vilmer E. Intermittent hemophagocytic Iymphohistiocytosis is a regular feature of Iysinuric protein intolerance. J Pediatr 1999;134:236-9.

11. Balta G, Okur H, Unal S, Yarali N, Gunes AM, Unal S, Turker M, Guler E, Ertem M, Albayrak M, Patiroglu T, Gurgey A. Assessment of clinical and laboratory presentations of familial hemophagocytic lymphohistiocytosis patients with homozygous W374X mutation. Leuk Res 2010;34:1012-7.

12. Gurgey A, Unal S, Okur H, Orhan D, Yurdakok M. Neonatal primary hemophagocytic lymphohistiocytosis in Turkish children. J Pediatr Hematol Oncol 2008;30:871-6.

13. Okur H, Balta G, Akarsu N, Oner A, Patiroglu T, Bay A, Sayli T, Unal S, Gurgey A. Clinical and molecular aspects of Turkish familial hemophagocytic Iymphohistiocytosis patients with perforin mutations. Leuk Res 2008;32:972-5.

14. Oren H, Gülen H, Uçar C, Duman M, İrken G. Successful treatment of infection- associated hemophagocytic syndrome with intravenous immunoglobulin. Turk J Hematol, 2003;20:95-9. 